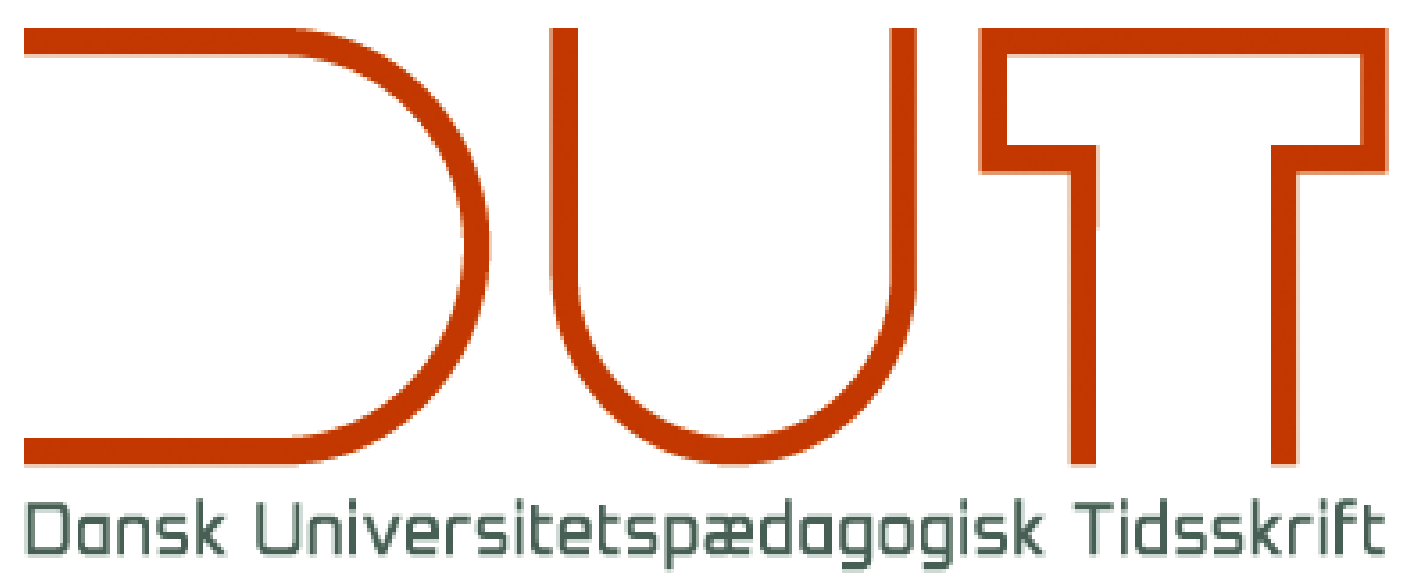

Læringsrum

Årgang 14 nr. 27 / 2019

Titel

Skriveretreat for specialestuderende: Et produktivt rum

Forfattere

Vibeke Ankersborg

Sidetal

3-19

Udgivet af

Dansk Universitetspædagogisk Netværk, DUN

URL

> http://dun-net.dk/

Betingelser for brug af denne artikel

(c) Copyright
Denne artikel er omfattet af ophavsretsloven, og der må citeres fra den. Følgende betingelser skal dog være opfyldt:

- Citatet skal være i overensstemmelse med "god skik"

- Der må kun citeres „i det omfang, som betinges af formålet“

- Ophavsmanden til teksten skal krediteres, og kilden skal angives ift. ovenstående bibliografiske oplysninger.

DUT og artiklens forfatter 


\title{
Skriveretreat for specialestuderende: Et produktivt rum
}

\author{
Vibeke Ankersborga, 1 \\ aStudent Affairs, Copenhagen Business School
}

Faglig artikel, fagfællebedømt

\begin{abstract}
Specialestuderende udsættes for organisatorisk pres for at skrive speciale på normeret tid. Skriveretreat har vist sig at øge forskeres produktivitet, og fra et produktivitetsperspektiv viser artiklen gennem analyse af data indsamlet over fire år fra 12 skriveretreat afholdt på universitetet med 135 respondenter, hvordan og hvorfor Murray \& Newton (2009)'s model for struktureret skriveretreat for forskere kan tilpasses til en virksom model for specialestuderende. Modellen består af en klar struktur, et fast program, et offlinerum samt facilitators lederskab og introducerer begrebet befriende tvangselement. Denne kombination gør skriveretreat til et fristed for studerende til alene at koncentrere sig om specialet. På baggrund af Murray, Steckley \& MacLeod (2012)'s teoretiske model for struktureret skriveretreat vises, hvordan og hvorfor der også på skriveretreat for specialestuderende sker både en organisatorisk, emotionel og epistemologisk indkapsling, der øger de studerendes skriveproduktivitet, deres indsigt i specialearbejdsformer samt deres viden om specialeprocessen.
\end{abstract}

\section{Indledning}

I 2016 indførte Copenhagen Business School, herefter CBS, faste specialeafleveringsfrister, der er fælles for alle kandidatuddannelserne. Samtidig blev det indskærpet, at de studerende har brugt et eksamensforsøg, hver gang de overskrider en afleveringsfrist, uanset om de har en gyldig specialekontrakt. Sidetalskravet for specialer blev dog ikke sænket, og de studerende skal derfor skrive speciale af samme omfang som før 2016, men på kortere tid. Dette øgede organisatoriske pres på de studerendes produktivitet gav anledning til at revidere de studieunderstøttende aktiviteter for specialestuderende, som CBS i mange år har udbudt for at fremme de studerendes mulighed for at skrive speciale på normeret tid uden at gå på kompromis med den faglige kvalitet. Revisionen af udbud medførte blandt andet, at CBS indførte skriveretreat for specialestuderende.

Ordet retreat betyder at trække sig tilbage (udsagnsord) til et fristed (navneord), og der er derfor tale om et skriveretreat, når en gruppe af personer trækker sig tilbage fra den omgivende verden i en fastsat tidsperiode for at skrive tekst til en planlagt publikation. I denne artikel er den planlagte publikation kandidatspecialet, og deltagerne er specialestuderende, der skriver på hver deres speciale. Skriveretreatet er rammesat af et fast program, der faciliteres af en medarbejder ved universitetet, og foregår på universitetets grund. Der er således ikke tale om studiegrupper, defineret som en mindre gruppe studerende, der mødes regelmæssigt for at diskutere deres løbende arbejde, ofte uden deltagelse af en universitetsmedarbejder.

\footnotetext{
${ }^{1}$ Kontakt: va.stu@cbs.dk
} 
I litteraturen om forskning i skriveretreat i akademia foregår retreat primært som internat. Skriveretreat har typisk tjent til at fremme deltagernes mulighed for at publicere, og skriveretreat er således undersøgt i et produktivitetsperspektiv. Dette ses for eksempel i litteraturstudiet af Kornhaber et al. (2016), hvor deltagerne typisk er forskere, uerfarne såvel som erfarne, men ikke studerende. Kornhaber et al. (2016)'s omtale af skriveinterventioners positive betydning for kandidatstuderende henviser således til litteratur om skrivegrupper, ikke skriveretreat (s. 1224). Disse tendenser genfindes også i andre artikler om skriveretreat, for eksempel Moore (2003), der er en af de tidligste artikler om skriveretreat, Swaggerty et al. (2011) med fokus på kvindelige akademikere, Girardeau et al. (2014) om yngre forskere samt Davis et al. (2016) om et endagsretreat for ph.d.-studerende. En undtagelse er Paltridge (2016), der udover unge forskere også har kandidatstuderende på sine skriveretreat.

Professor Rowena Murray er blandt de mest publicerende (f.eks. Murray \& Newton, 2009; Moore, Murphy \& Murray, 2010; Murray, Steckley \& MacLeod, 2012) og citerede forskere om skriveretreat, som hun også selv afholder (Anchorage Education, 2019). Sammen med Mary Newton har Murray evalueret en dengang ny form for struktureret skriveretreat, hvor deltagerne arbejder i samme lokale og følger et fastlagt program, der er styret af en facilitator (Murray \& Newton, 2009). CBS' skriveretreat for specialestuderende bygger på Murray \& Newton (2009)'s model for struktureret skriveretreat. Dog blev modellen forud for afholdelsen af det første skriveretreat modificeret, både i form af at deltagerne udelukkende er specialestuderende, at der indgår et større miks af aktiviteter i programmet for skriveretreatet, og at det ikke foregår som internat.

Dickson-Swift et al. (2009) er en af de få kilder til skriveretreat, der ikke er afholdt som internat. Dickson-Swift et al. tager afsæt i udfordringen med at finde tid til at skrive uforstyrret indimellem andre arbejdsopgaver, såsom undervisning, og dermed indfri nationale krav om øget publicering (Dickson-Swift et al., 2009, s. 229-231). Også de anlægger således et produktivitetsperspektiv på skriveretreat. For Dickson-Swift og hendes kollegaer blev løsningen at lave skriveretreat på deres eget universitet, men afsondret fra omgivelserne. Her lykkedes det dem at opnå samme 'lukke verden ude'-effekt, som der er på internatretreat, og skabe et produktivt skrivemiljø (Dickson-Swift et al., 2009, s. 233). Ansattes arbejdsvilkår kan ikke umiddelbart overføres til fuldtidsstuderendes, men der er paralleller, f.eks. at også specialestuderende er underlagt organisatorisk pres. Artiklen inspirerede således til, at det kunne være muligt at afholde skriveretreat for specialestuderende på universitetet frem for som internat.

Denne artikels analyse bygger på løbende dataindsamling fra opstarten i februar 2016 til april 2019 fra i alt 15 afholdte skriveretreat. Analysen giver et indblik i, hvor udbytterig de studerende selv vurderer, at de enkelte dele af skriveretreatet har eller ikke har været for deres produktivitet og dermed også, hvorfor indholdet er blevet ændret over tid. Udbytte står for, om skriveretreatet har hjulpet de studerende til at arbejde mere effektivt med deres speciale, og artiklen anlægger således et produktivitetsperspektiv i tråd med den ovenfor nævnte tendens i litteraturen.

I det følgende udfoldes først konceptet for struktureret skriveretreat. Herefter analyseres strukturens betydning, der forklares gennem en teoretisk model udviklet af Murray i samarbejde med Laura Steckley og lain MacLeod (Murray et al., 2012) om specifikt denne type skriveretreat. Dernæst analyseres indholdselementerne, inddelt i skriveaktiviteter og dialogaktiviteter. På baggrund af analysen rundes artiklen af $\mathrm{i}$ konklusionen med et bud på den modifi- 
cering af Murray \& Newtons strukturerede skriveretreat, der giver den mest hensigtsmæssige ramme for høj produktivitet set fra studenterperspektiv på et dansk universitet, og som dermed støtter de studerende i at skrive speciale på normeret tid.

\section{Den organisatoriske forankring}

På CBS har de specialestuderende adgang til en række ressourcer, der har til formål at understøtte de studerendes specialeskrivning. Ressourcerne er både analoge og digitale og består blandt andet af en videoserie om specialeskrivning produceret af CBS, et online univers, et e-læringsfag, webinarer, seminarer, individuel procesvejledning samt denne artikels tema; skriveretreat for specialestuderende. Specialeressourcernes faglige indhold handler blandt andet om skriveprocesser, tekst- vs. videnproduktion, brug af vejleder, projektmetode og gruppesamarbejde. Samtidig legitimerer specialeressourcernes eksistens overfor de studerende, at de ikke forventes at vide alt om specialeskrivning på forhånd. Dette signal gør det i sig selv nemmere for de studerende at bruge ressourcerne.

Specialeressourcerne, herunder skriveretreat, står til rådighed for alle specialestuderende fra samtlige kandidatuddannelser på CBS, og de studerende bestemmer selv, hvilke af specialeressourcerne de ønsker at anvende, og i hvilket omfang de vil anvende dem. Ansvaret for at udvikle og implementere specialeressourcerne er organisatorisk forankret i afdelingen Student Affairs, og det er inden for denne ramme, at skriveretreat for specialestuderende udbydes. Skriveretreatene faciliteres af denne artikels forfatter, der er specialekonsulent med underviserbaggrund.

Omkostningsmæssigt tager et skriveretreat 9 timer at afholde. Herudover skal skriveretreatet formidles til de studerende, og der skal etableres en tilmeldingsprocedure. Forud for det første skriveretreat skal der produceres slides i henhold til programmet, hvorefter der kan være behov for løbende justeringer. Facilitator bør besidde kompetencer til at lede et klasserum, da lederskabet er centralt for skriveretreatets succes. Endvidere er indsigt i akademisk tekst- og videnproduktion en fordel.

\section{Koncept for skriveretreat for specialestuderende}

Skriveretreat for specialestuderende foregår over to dage, kl. 13.00-17.00 dag 1 og kl. 10.0015.00 dag 2. Der deltager ca. 20 specialestuderende på hvert skriveretreat, hvor de arbejder individuelt på deres eget speciale, men sidder i samme lokale i små, faste grupper, så de sparrer med de samme medstuderende igennem hele skriveretreatet. Grupperne dannes tilfældigt, som de studerende møder frem den første dag. Skriveretreatet foregår enten på dansk, engelsk eller er tosproget, hvilket vil sige, at det faciliteres på engelsk, men at de studerende taler et sprog efter eget valg.

Et væsentligt aspekt ved denne type skriveretreat er den strukturerende ramme, der dels består af et sæt regler for adfærd, dels af et program med indholdselementer. Reglerne skal bidrage til de bedst mulige arbejdsbetingelser og består i, at rummet skal være offline, at der skal være tavshed i skriveperioderne, at pauserne skal bruges til at holde pause, og at viden om andre deltageres specialer behandles fortroligt efter skriveretreatet. Indholdselementerne består af koncentreret skrivning, arbejde med forskellige skriveteknikker, dialog med ligesindede og pauser, der tilsammen skaber en vekselvirkning og introducerer de studerende til forskellige måder at arbejde på. På CBS' skriveretreat for specialestuderende indgår der et større miks af skriveteknikker i programmet end beskrevet af Murray \& Newton (2009). Dette skyldes, at nogle specialestuderende ikke formår at anvende skriveteknikker i deres speciale- 
proces, selvom de er blevet undervist i dem, og selvom de evner at omsætte anden viden fra undervisningen, f.eks. om metode, i specialeprocessen (Ankersborg \& Pogner, 2016). Et afledt formål med CBS' skriveretreat for specialestuderende er derfor at træne de studerende i forskellige teknikker, der kan forbedre deres skriveproces, når de arbejder på egen hånd. Dette uddybes i det følgende, men det er ikke et formål med nærværende artikel at bidrage til litteraturen om peer feedback og skriveteknikker ud over det, der er relevant inden for rammerne af skriveretreatet.

Indholdselementerne foregår på klokkeslæt og er stramt styret af facilitator. Det aktuelle element med handlingsanvisning og varighed vises på et slide. Programmet for det senest afholdte skriveretreat fremgår af figur 1. De enkelte indholdselementer uddybes i det følgende.

\begin{tabular}{|c|c|}
\hline Program dag 1 & Program dag 2 \\
\hline 13.00: Intro & 10.00: Godmorgen - revider dit mål \\
\hline 13.05: Præsentation I grupperne & 10.10: Opvarmning non-stop; stikord fra i går \\
\hline 13.15: Sæt dig et mål for retreat & 10.15: Skriveheat \\
\hline 13.25: Non-stop skrivning & 11.15: Pause \\
\hline 13.45: Pause & 11.30: Udbyg teksten - pen på papir \\
\hline 14.00: Skriveheat & 12.00: Arbejdsfrokost; frokostconversation med feedback \\
\hline 15.25: Pause & 12.30: Skriveheat \\
\hline 15.40: Feedback-feed forward & 13:30: Pause \\
\hline 16.00: Skriveheat & 13.45: Skriveheat \\
\hline 16.50: Hvor vil du fortsætte? & 14.50: Tjek dit mål + de næste skridt \\
\hline \multirow[t]{2}{*}{ Stikord til i morgen } & 14.55: Evaluering \\
\hline & 15.00: Tak for denne gang \\
\hline
\end{tabular}

Figur 1. Program for skriveretreat april 2019

I modsætning til Murray \& Newtons skriveretreat foregår CBS' skriveretreat for specialestuderende som nævnt på universitetet. Det løser en praktisk/økonomisk udfordring ved, at de studerende sover hjemme og selv sørger for forplejning, hvorfor konceptet for skriveretreat for specialestuderende ikke medfører ekstraudgifter for CBS. En af udfordringerne ved skriveretreat på universitetet er dog ifølge Dickson-Swift et al. (2009, s. 233) fristelsen til at lade sig forstyrre af det daglige liv. Dette nævnes også af Paltridge (2016, s. 201), der flyttede sit skriveretreat fra universitetet til internat af samme grund. Også for nogle af de specialestuderende på CBS har dette vist sig at være et problem. De første versioner af omtalen af skriveretreatet på specialeseminarrækkens e-læringsplatform forklarede ikke, hvorfor det er vigtigt, at alle deltagere overholder reglerne, men kun hvad reglerne bestod i. Den seneste version af omtalen, der er blevet brugt i 2018 og 2019, har imidlertid haft en positiv effekt på de studerendes adfærd:

Skriveretreat betyder at lukke verden ude for at få ro til at skrive, dvs. at vi går i skrivehi sammen. Til skriveretreat for specialestuderende samler vi en gruppe specialestuderende $i$ samme rum og faciliterer skriveprocessen. Strukturen på retreatet og betingelserne for at deltage bygger på forskning i skriveretreat afholdt på andre universiteter og er skabt med henblik på at skabe et produktivt miljø for specialeskrivning. Det er derfor afgørende, at alle deltagere overholder betingelserne til fulde. Hvis du ikke har lyst til at følge reglerne, kan du blot lade vore med at tilmelde dig. 
Du arbejder hurtigere og udnytter tiden mere effektivt, hvis du i perioder lukker verden ude. Afbrydelser tvinger dig til at gå bagloens i en igangvaerende undersøgelse, før du kan arbejde videre.

At lukke verden ude skal derfor forstås bogstaveligt. Hvis du vil deltage, SKAL du acceptere at lukke verden ude og deltage BEGGE dage i det fulde tidsrum. Mobiltelefonen skal voere slukket og e-mailen lukket, du skal ikke på arbejde, til vejledermøde eller hente børn. Du skal koncentrere dig om at skrive speciale. Det er utroligt forstyrrende for de andre studerende, hvis bare én studerende bryder reglerne. Til gengald er det utroligt berigende at vore produktiv sammen med andre i samme situation. (E-loeringsfag, 2019)

Ovenstående til trods kræver det dog facilitators stadige bevågenhed at sikre, at alle deltagere følger reglerne, hvilket uddybes i det følgende.

\section{Datagrundlag}

Fra februar 2016 til april 2019 er der afholdt 15 skriveretreat. Af de 15 afholdte retreat blev de 12 evalueret på stedet via et elektronisk spørgeskema. De tre skriveretreat i foråret 2018 blev ikke evalueret.

I alt har 134 studerende besvaret evalueringsskemaet. 305 studerende tilmeldte sig de 12 evaluerede skriveretreat, men ikke alle tilmeldte mødte frem til de enkelte retreat. Det er derfor ikke muligt at udregne den præcise svarprocent. Ét skriveretreat blev som forsøg afholdt som endagsretreat, og det bliver sidst i artiklen behandlet særskilt. For dette retreat er $\mathrm{N}=10$, og svarprocenten er mindst $34 \%$. For de 11 evaluerede todagsretreat er $\mathrm{N}=124$, og svarprocenten er mindst $45 \%$. Det er disse 11 skriveretreat, der vises i diagrammerne i det følgende.

Evalueringsskemaet består både af en kvantitativ del og en kvalitativ del. I den kvantitative del bliver de studerende bedt om at vurdere deres udbytte af de enkelte indholdselementer på en skala fra 1 til 5, hvor 1 er lig med intet udbytte, og 5 er lig med højt udbytte. De studerende er specifikt blevet bedt om at vurdere udbytte og ikke tilfredshed, da formålet med evalueringerne er at skabe den sammensætning af indholdselementer, der giver de studerende den højeste produktivitet.

Den kvantitative del er databehandlet ved simpel sammentælling. Da $\mathrm{N}=124$ er antal besvarelser ikke omregnet til procent, men vises som faktisk antal i diagrammerne nedenfor. Som følge af evalueringerne har der været udskiftning af indholdselementer i løbet af de fire års skriveretreat, og derfor er nogle af indholdselementerne ikke evalueret alle 11 gange, hvilket fremgår af datakategorierne i diagrammerne.

I den kvalitative del med åbne svarkategorier bliver de studerende bedt om at svare på spørgsmålene: "Hvad var det bedste ved at deltage i skriveretreat?", hvortil data rummer 143 svar plus 10 svar fra endagsretreatet, og: "Har du ændringsforslag?", hvortil data rummer 120 svar plus 10 svar fra endagsretreatet. Svarene er organiseret kronologisk efter tidspunktet for retreatet, da de enkelte svar forholder sig til den konkrete version af skriveretreatet, som respondenten har deltaget i, og indholdselementerne på de enkelte retreat som nævnt er ændret undervejs. Dette gør det muligt at følge en eventuel udvikling i svarene på tværs af de afholdte skriveretreat i takt med ændringerne af indholdet. Herefter er kommentarerne kodet ud fra indholdselementerne på og reglerne for skriveretreat for at skabe et nuanceret indblik i, hvordan og hvorfor skriveretreatets enkelte bestanddele har eller ikke har en positiv 
indflydelse på de studerendes produktivitet i deres egen optik. I det følgende henvises der til de kvalitative kommentarer med (retreat måned år).

\section{Struktur og rum}

Murray, Steckley og MacLeods teoretiske model (Murray et al., 2012) forklarer, hvorfor struktureret skriveretreat af den type, der er beskrevet i Murray \& Newton (2009), og som CBS' skriveretreat for specialestuderende bygger på, medfører en øget skriveproduktivitet. Modellens overbegreb holistic containment inddeler de i organisational, emotional og epistomological containment, som jeg her oversætter til indkapsling. Når alle tre typer indkapslinger er til stede, har deltagerne på skriveretreatet en højere produktivitet (Murray et al., 2012, s. 773). Herudover indeholder modellen begrebet strategic engagement, der står for den langtidsholdbare effekt af skriveretreatet på deltagernes skrivevaner. Data fra CBS' skriveretreat for specialestuderende rummer ikke nogen mulighed for at undersøge strategic engagements effekt på specialestuderende.

I det følgende anvendes holistic containment-modellen til at undersøge, hvorfor også specialestuderende oplever en øget produktivitet, når de deltager i et skriveretreat. Brugen af pauser samt det fysiske rum behandles sidst i dette afsnit, da begge dele indgår i den strukturerende ramme, der omgiver de studerende.

Organisatorisk indkapsling består i den klare struktur, som deltagerne arbejder inden for (Murray et al., 2012, s. 770). På tværs af skriveretreatene er en af de klare tendenser i kommentarerne, at det bedste ved at deltage i skriveretreatet er den strukturende ramme og det arbejdsklima, som denne ramme skaber. Selve dette, at en facilitator bestemmer, hvornår de studerende skal skrive, hvornår de skal holde pause, og hvilke skriveteknikker de skal anvende, øger ifølge de studerende selv deres produktivitet. Således har 94 af respondenterne haft et højt udbytte (score 4-5) af at skrive i et struktureret forløb (se figur 2). Facilitators lederskab er en væsentlig komponent i holistic containment-modellen, da lederskabet har betydning for, om strukturen skaber den organisatoriske indkapsling, der tvinger deltagerne til at holde fokus på at skrive (Murray et al., 2012, s. 771). 


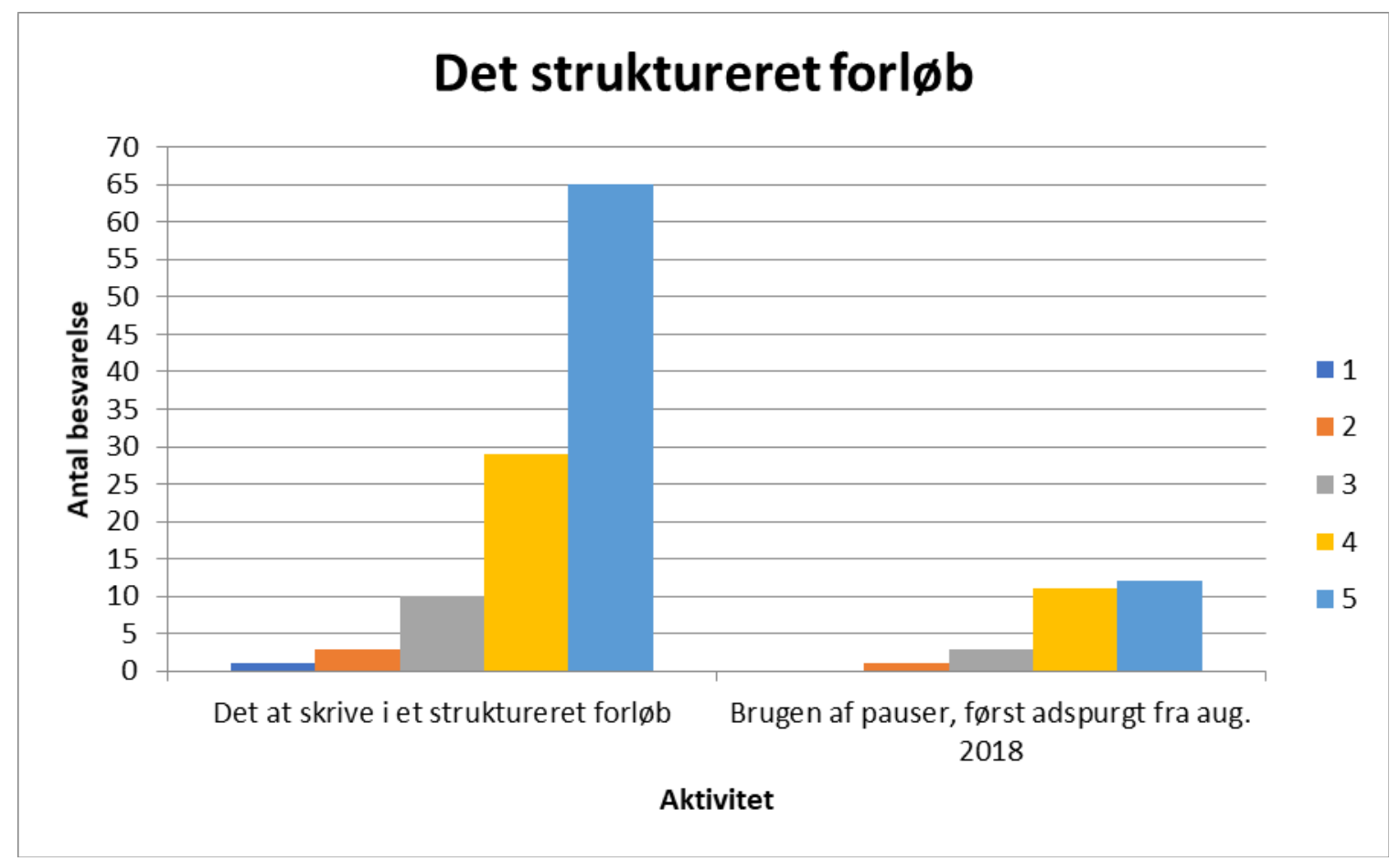

Figur 2. De studerendes udbytte af at skrive i et struktureret forløb (Score: 1 = intet udbytte, 5 = stort udbytte)

På skriveretreat for specialestuderende indgår også reglerne for adfærd i den organisatoriske indkapsling, og en anden tendens i data er, at forbuddet mod mobiltelefoner, e-mail og sociale medier har en positiv indflydelse på de studerendes koncentration: "Dejligt at forsøge at være offline og kun koncentrere sig om dette [specialet] og ikke arbejdsmail, telefon osv." (retreat marts 2019). At holde det fysiske rum offline kræver dog i praksis, at facilitator bruger sin autoritet til at insistere på, at reglerne overholdes. På alle 15 afholdte skriveretreat har der været studerende, der ikke fulgte reglerne, hvilket har medført kommentarer i evalueringerne om, at facilitator godt må håndhæve reglerne konsekvent. Også her ses lederskabets betydning for, at der kan skabes organisatorisk indkapsling.

Arbejdsklimaet har betydning for emotionel indkapsling, der handler om at indkapsle overspringshandlinger, manglende disciplin o.l. ved, at facilitator støtter deltagerne og tvinger dem til at holde fokus på skrivningen (Murray et al., 2012, s. 770). Det element af tvang, som strukturen skaber, virker ikke hæmmende, men befrier tværtimod de studerende fra forstyrrelser. Således skriver en studerende, at hun nød skriveretreatet, fordi det tvang hende til at arbejde på specialet uden at blive distraheret (retreat august 2017), mens en anden studerende vægter den pålagte skrivetvang, der forhindrer hende i kun at læse uden at skrive (retreat august 2017).

Epistemologisk indkapsling består i at få det konkrete projekt og skriveprocesser generelt til at give mening (Murray et al., 2012, s. 773). På tværs af de enkelte skriveretreat er der studerende, der ikke blot har produceret tekst, men også fået ny indsigt i deres tekst, som f.eks. denne studerende, der skriver om det bedste ved skriveretreatet: "Det var at få slået hul på analysen i mit speciale. Det føltes som et rigtig vigtigt tidspunkt at få det gjort, fordi vi fik mere retning på vores kommende skrivning. Der er både blevet produceret tekst, samt fået sat en masse tanker i gang om den kommende proces" (retreat marts 2019). 
Endvidere består epistemologisk indkapsling $\mathrm{i}$ at erkende skrivning som en del af den akademiske identitet. Murray et al.'s empiri består af forskere, for hvem det at publicere er en del af jobbet. Det er ikke muligt på baggrund af data at vurdere om denne del af epistemologisk indkapsling også gælder for specialestuderende.

Organisatorisk indkapsling er en forudsætning for at skabe emotionel og epistemologisk indkapsling, og hvordan de tre indkapslinger fletter sig ind i hinanden i praksis, illustreres af denne studerende: "Det var helt klart at få taget hul på selve skrivningen. Jeg havde ikke skrevet et eneste ord inden, fordi jeg nok var lidt bange for sådan rigtigt at gå i gang og hvor man lige skulle starte etc. Men her var der ligesom bare en som sagde, at man skulle skrive. Og nu er jeg i gang og det føles rigtig godt. Derudover var det også rigtig godt at snakke med andre og finde ud af, hvor de er i deres proces og hvilke tanker og overvejelser de har. Det giver ro i maven" (retreat marts 2019).

Det enkeltelement på skriveretreatet, som det er nemmest for de studerende at skabe selv, er det uforstyrrede, stille, offline rum. På CBS kan de studerende for eksempel arbejde i et specialelokale. Alligevel bliver netop dette element fremhævet i kommentarerne om det bedste ved at deltage i skriveretreat. De studerende skriver blandt andet, at det bedste var at blive placeret i et miljø uden distraktioner (retreat 2 marts 2017), at effekten var at få løst et problem på to dage, der har generet i to måneder (retreat april 2016), samt at kunne arbejde hårdt to dage i træk uden forstyrrelser. Som flere andre tilføjer denne studerende tilmed et eksplicit "tak" (retreat 2 marts 2017). Så selvom det også for forskere er befordrende for skriveproduktiviteten at forlade kontoret og de daglige arbejdsopgaver (Dickson-Swift et al., 2009 , s. 235), synes det befriende tvangselement at have en ekstra dimension for de specialestuderende. Facilitators autoritet som repræsentant for universitetet leverer den perfekte undskyldning for de studerende til alene at koncentrere sig om specialet og faktisk lukke verden ude i disse to dage, hvilket synes at være en sjælden, men kærkommen oplevelse.

\section{Brugen af pauser}

Skriveretreatets inddeling i indholdselementer er til dels praktisk funderet. I rum, hvor flere personer arbejder i koncentreret stilhed, kan selv mindre uro, som at én person rejser sig for at gå på toilettet, virke forstyrrende. Derfor er der en ufravigelig regel om, at alle skal være stille og blive siddende i skriveheatene (se nedenfor). Derfor må der nødvendigvis også være skemalagte pauser. De studerende bliver opfordret til ikke at arbejde i pauserne, men i stedet at gå lidt rundt uden for lokalet, også selvom de ikke har et udtalt behov. Brugen af pauser indgår kun i den kvantitative del af evalueringsskemaet fra august 2018, og 23 ud af 27 studerende angiver, at det gav dem et højt udbytte (score 4-5) at holde pauser (se figur 2). To studerende fra de forudgående skriveretreat mener, at pauserne var for lange, mens andre studerende omtaler pausernes positive effekt som et af de elementer, de selv vil bruge efter retreatet, blandt andet fordi pauserne i sig selv har en fokuserende og disciplinerende effekt, idet de forhindrer uendelige arbejdsdage. Denne betydning af pauser genfindes på Papen \& Thériaults (2018, s. 173) skriveretreat, hvor pauser mellem skriveheatene både gav deres ph.d.-studerende mere selvdisciplin på selve retreatet og en bedre skriverytme efter retreatet. Brugen af pauser bidrager således både til den organisatoriske og den emotionelle indkapsling. Det er dog ikke alle studerende, der finder sig til rette i dette miljø. På tværs af retreatene har der været enkelte studerende, der ved slutningen af dag 1 sagde, at de ikke ville deltage i dag 2. 


\section{Det fysiske rum}

Det fysiske rum er et mindre undervisningslokale, om muligt et der er nyrenoveret med gode stole og nem adgang til strøm. De ændringsforslag til det fysiske rum, der er i data, handler om besværlig adgang til strøm i lokaler, der endnu ikke var renoveret, da retreatet blev afholdt. Ifølge lektor Tina Keiding kan det fysiske rum have indflydelse på studerendes oplevelse af at være en del af et større fællesskab, idet fælles fysiske rammer i modsætning til lukkede døre kan virke befordrende på studerendes indbyrdes sparring (Keiding, 2012, s. 46-47). Keiding har undersøgt de fysiske rammer for gruppeprojekter på et dansk universitet, ikke skriveretreat, men hendes resultater understøtter antagelsen om, at det at sidde i samme lokale på et skriveretreat for grupper bidrager til det mentale rum, som strukturen og deltagerne skaber sammen, og som de fleste kommentarer i data om rummet handler om. Det kan således antages, at det fælles fysiske rum bidrager til både den emotionelle og den epistemologiske indkapsling.

\section{Indholdselementer: Skriveaktiviteter}

I dette afsnit behandles indholdselementerne skriveheat og skriveteknikker (se figur 3 og 4).

Skriveheat er det mest centrale indholdselement på skriveretreat. Et skriveheat varer 50 til 90 minutter og følger deri Murray \& Newton (2009)'s program. De studerende bestemmer selv, hvordan de vil arbejde med deres speciale. Den eneste regel er, at det skal foregå i stilhed.

På tværs af de enkelte retreat er skriveheaterne det enkeltelement, der giver flest studerende et højt udbytte (score 4-5) med 95 studerende for skriveheat 1, dag 1 og 93 studerende for skriveheat 1, dag 2, der begge har været en del af programmet på samtlige skriveretreat (se figur 3). Som konsekvens af evalueringerne er der sket en gradvis stigning i antallet af skriveheat pr. skriveretreat, og skriveretreatene i august 2018 og foråret 2019 har således haft det hidtil højeste antal skriveheat. Der er ingen ændringsforslag i data fra august 2017 og august 2018, der angiver, at skriveheatene optog for meget plads, og der er ingen eksplicitte forslag fra disse retreat om mere tid til andre aktiviteter. Derimod skriver tre ud af 20 studerende på retreatene i marts og april 2019, at det sidste skriveheat på dag 2 var knapt så produktivt, og der er fem forslag om andre aktiviteter. Endvidere er der på tværs af retreatene enkelte kommentarer om, at 90 minutter er lidt for lang tid uden pause, mens ingen studerende foreslår, at et skriveheat bør vare længere end 90 minutter. Den ideelle varighed af et skriveheat ser således ud til at være 60-75 minutter, og det samlede antal skriveheat pr. retreat bør ikke være højere end de nuværende 5 (se figur 1). 
Skriveheat

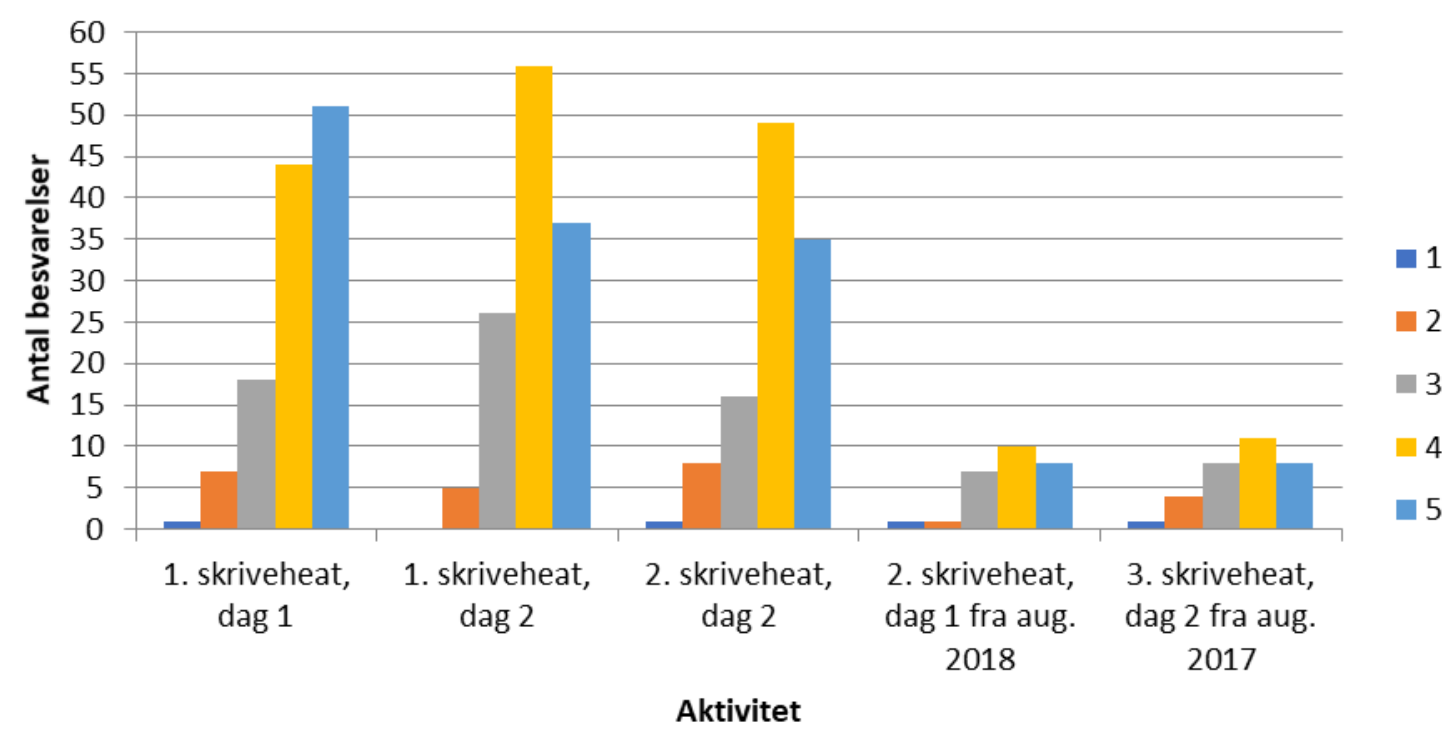

Figur 3. De studerendes udbytte af skriveheatene (Score: 1 = intet udbytte, 5 = stort udbytte)

Som med reglen om, at rummet er offline, var der især på de første skriveretreat enkelte studerende, der ikke forstod, at reglen om stilhed betød, at også de skulle være stille. Det er således nødvendigt, at facilitator grundigt forklarer, hvorfor brud på reglerne ødelægger koncentrationen for de øvrige studerende. Risikoen for, at nogle deltagere forstyrrer de øvrige skrivere, omtales ikke hos hverken Dickson-Swift et al. (2009) eller Murray \& Newton (2009). Dette indikerer, at skriveretreat for specialestuderende kræver en strammere styrring end skriveretreat for forskere for at lykkes, også selvom deltagelse er frivillig for de studerende. Også her ses lederskabets betydning for den holistiske indkapsling.

Som tidligere nævnt er der et større miks af skriveteknikker i programmet for CBS' skriveretreat for specialestuderende, end der er i Murray \& Newton (2009)'s program for struktureret skriveretreat. I den første version af skriveretreatet i foråret 2016 blev skriveteknikkerne valgt ud fra et ønske om variation, men skriveteknikkerne har haft en vekslende indflydelse på produktiviteten, og der er derfor foretaget justeringer undervejs (se figur 4). 


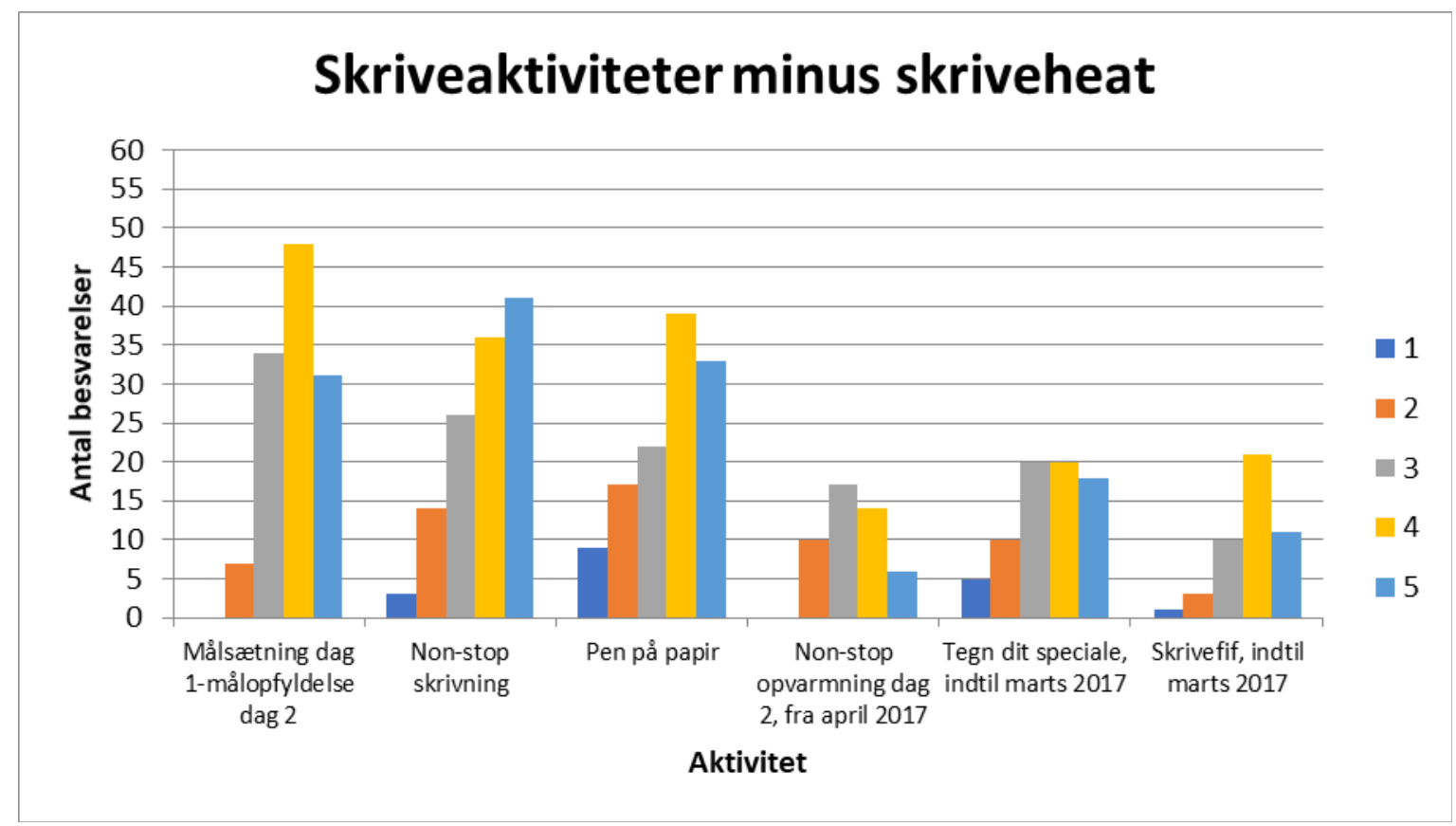

Figur 4. De studerendes udbytte af øvrige skriveaktiviteter (Score: $1=$ intet udbytte, $5=$ stort udbytte)

Målsœetning-målopfyldelse rammer de studerendes arbejde ind. Det er den første aktivitet på dag 1, hvor de studerende skriver, hvad de vil producere på skriveretreatet og deler deres målsætning med gruppen. Dag 2 starter med en revision af målsætningen, der også deles med gruppen, og afsluttes med, at de studerende sammenholder målsætning og produktion som retreatets sidste aktivitet. Målsætning-målopfyldelse bygger på Murray \& Newton (2009)'s todages internatretreat og Morss \& Murray (2001)'s seksmåneders skriveprogram. Det er ikke hensigten, at de studerende faktisk skal indfri deres egen målsætning. Teknikken tjener til at holde fokus og som afsæt for at tale om det løbende arbejde med de andre deltagere (Murray \& Newton, 2009, s. 545). For de specialestuderende tjener det endvidere til illustration af, at de ifølge deres egne kommentarer arbejder mere effektivt inden for skriveretreatets strukturende ramme end udenfor. Målsætning-målopfyldelse har været en del af programmet på alle skriveretreat, og 79 ud af 120 studerende har haft et højt udbytte (score 4-5) af denne teknik, se figur 4.

Skrivefif var et oplæg af facilitator om skriveteknikker, der ikke bliver anvendt på skriveretreatene, men som de studerende selv kan anvende i andre sammenhænge. 32 ud af 46 studerende havde et højt udbytte af dette oplæg (score 4-5), men det nævnes stort set ikke i de positive kommentarer i modsætning til de teknikker, som de studerende faktisk anvender på skriveretreatet. De få ændringsforslag, der er om skrivefif, anbefaler at flytte oplægget til en anden del af retreatet, hvilket indikerer, at det var lidt i vejen. Oplægget blev fjernet, dels for at skabe mere tid til skriveheat, og dels fordi indholdet fagligt passer bedre ind $\mathrm{i}$ et specialeseminar, der afholdes på et andet tidspunkt i samme semester.

Tegn dit speciale indgik i programmet til og med marts 2017. Øvelsen bestod i, at de studerende fik udleveret et ark papir med Toulmins argumentmodel tilføjet tomme bokse, som de studerende skulle udfylde enten på kapitelniveau eller specialeniveau med kapilets /specialets overordnet påstand med tilhørende belæg og hjemmeler. Denne måde at anvende Toulmins argumentmodel bygger i skriveretreatsammenhæng på Rienecker et al. (2016, s. 
76). 38 ud af 73 studerende havde et højt udbytte af denne øvelse (score 4-5), mens de resterende 35 studerende havde intet eller et begrænset udbytte (score 1-3). Af ændringsforslagene i data fremgår det, at en del studerende ikke forstod logikken i Toulmins argumentmodel og derfor havde svært ved at gennemføre øvelsen. Det må således konstateres, at denne øvelse havde en negativ effekt på for mange af de studerendes produktivitet, og at den nødvendige, grundigere instruktion ville have givet mindre tid til skriveheat.

Non-stop skrivning indgår to gange på skriveretreatet og følger reglerne opstillet af Rienecker (1996, s. 67-68). Non-stop er den anden aktivitet på retreatets første dag, hvor den varer 15 minutter. Hensigten er at sikre, at alle får skrevet noget og dermed kommer i gang med skrivningen med det samme. Enkelte studerende falder for fristelsen til at stoppe op undervejs, men $2 / 3$ af de studerende har et højt udbytte af denne øvelse (score 4-5), (se figur 4), og generelt skriver alle deltagere hurtigt og koncentreret, hvilket bidrager til at skabe energi i rummet.

Da øvelsen 'tegn dit speciale' og oplægget om skrivefif blev fjernet fra programmet efter skriveretreatene i marts 2017, og erfaringen fra 2016 havde vist, at dag 2 ikke kunne koldstarte med et skriveheat, blev der i april 2017 indført en non-stop øvelse på dag 2. Denne version af non-stop varer 5 minutter, og de studerende opfordres til at skrive specifikt om de stikord til dag 2, som er det allersidste, de skriver på dag 1. Dette tjener til at skabe en forbindelse mellem dag 1 og dag 2. 27 ud af 47 studerende har haft et begrænset udbytte (score 2-3) af nonstop dag 2, men der er ingen forklaringer på dette i de kvalitative kommentarer.

Pen på papir består af 30 minutters skrivning i hånden. Som udgangspunkt arbejder de studerende videre på samme tekst som på computeren, blot i hånden. 72 ud af 120 studerende har haft et højt udbytte (score 4-5) af at anvende denne teknik, der har været en del af programmet på alle skriveretreat. Forskning viser, at studerende lærer bedre, når de tager noter i hånden frem for på computeren (Mueller \& Oppenheimer, 2018), og formålet med dette indholdselement er derfor at udfordre de studerendes vanetænkning i forhold til pr. automatik at skrive på computeren.

Generelt om skriveteknikkerne skriver de studerende, at en af de bedste ting ved at være på skriveretreat er at lære forskellige teknikker at kende, der også kan anvendes efter retreatet, og som gør skriveprocessen mere varieret. Ændringsforslagene handler om specifikke elementer, som beskrevet ovenfor, mens fire studerende foreslår flere øvelser med skriveteknikker. Set fra et produktivitetsperspektiv er det således meningsfuldt at udbygge Murray \& Newton (2009)'s struktur med skriveteknikker på betingelse af, at teknikkerne kan anvendes umiddelbart efter en kort instruktion, og at de samlet set ikke optager for meget tid. Der er endda indikation af, at vekslen mellem typer af aktiviteter øger produktiviteten, da der synes at være en øvre grænse for antallet af skriveheat. Det er muligt, at samme effekt kan opnås ved at inddrage andre typer aktiviteter. F.eks. inddrager Paltridge (2016) øvelser i, hvordan man publicerer i videnskabelige tidsskrifter, på sine skriveretreat, som han har undersøgt i et pædagogisk perspektiv. Selvom skriveteknikøvelser ikke indgår i holistic containmentmodellen, kan øvelserne ses som en del af den epistemologiske indkapsling, da øvelserne øger de studerendes kendskab til skriveprocesser generelt.

\section{Indholdselementer: Dialogaktiviteter}

Selvom formålet med at deltage i et skriveretreat er at producere tekst, er der indlagt flere peer feedback- og dialogelementer i programmet. Baggrunden herfor er, at studerende på 
tidligere specialeseminarer har fremhævet muligheden for at tale med andre specialestuderende som en positiv sidegevinst ved seminarerne. Dette er i tråd med den generelt stigende udbredelse af peer feedback på danske universiteter (Hvass og Heger s. 59-60), og specielt i forhold til skriveretreat omtaler Dickson-Swift et al. (2009, s. 234) dialog med kollegaer om det igangværende skriveprojekt blandt de positive aspekter ved et fælles skriveretreat. Også Moore $(2003$, s. 338) fremhæver, at sparring med de øvrige deltagere på et skriveretreat fremmer produktiviteten, også selvom deltagerne på det af hende undersøgte skriveretreat skrev i separate rum og kun mødtes på udvalgte tidspunkter i løbet af retreatet.

I 2016-versionen af CBS' skriveretreat blev de studerende på dag 1 bedt om at fortælle om deres speciale til den gruppe, de sad i, og give kritik, foreslå ændringer mv. til hinanden. Herefter fik de 30 minutter til at notere feedbacken i deres egen tekst. Dette indholdselement indgår i "Feedback med revision, dag 1" i figur 5. På dag 2 skulle de studerende dels dele og kommentere en væsentlig udfordring (indgår i figur 5 i "Feedback med revision, dag 2") og dels interviewe hinanden om deres Toulminmodel ("Interview kun til og med april 2016" i figur 5). Der var dog ikke tilstrækkeligt udbytte af denne version af dialogelementerne, og 12 ud af 45 ændringsforslag fra skriveretreatene i foråret 2016 handlede således enten om at bruge mindre tid på feedback og mere tid på skrivning eller om at sammensætte grupperne på baggrund af faglighed, da de studerende har svært ved at forstå specialer fra andre fag. Dette forslag er endnu ikke implementeret i praksis, da det kræver mere forberedelse af facilitator at danne grupperne, før retreatet starter.

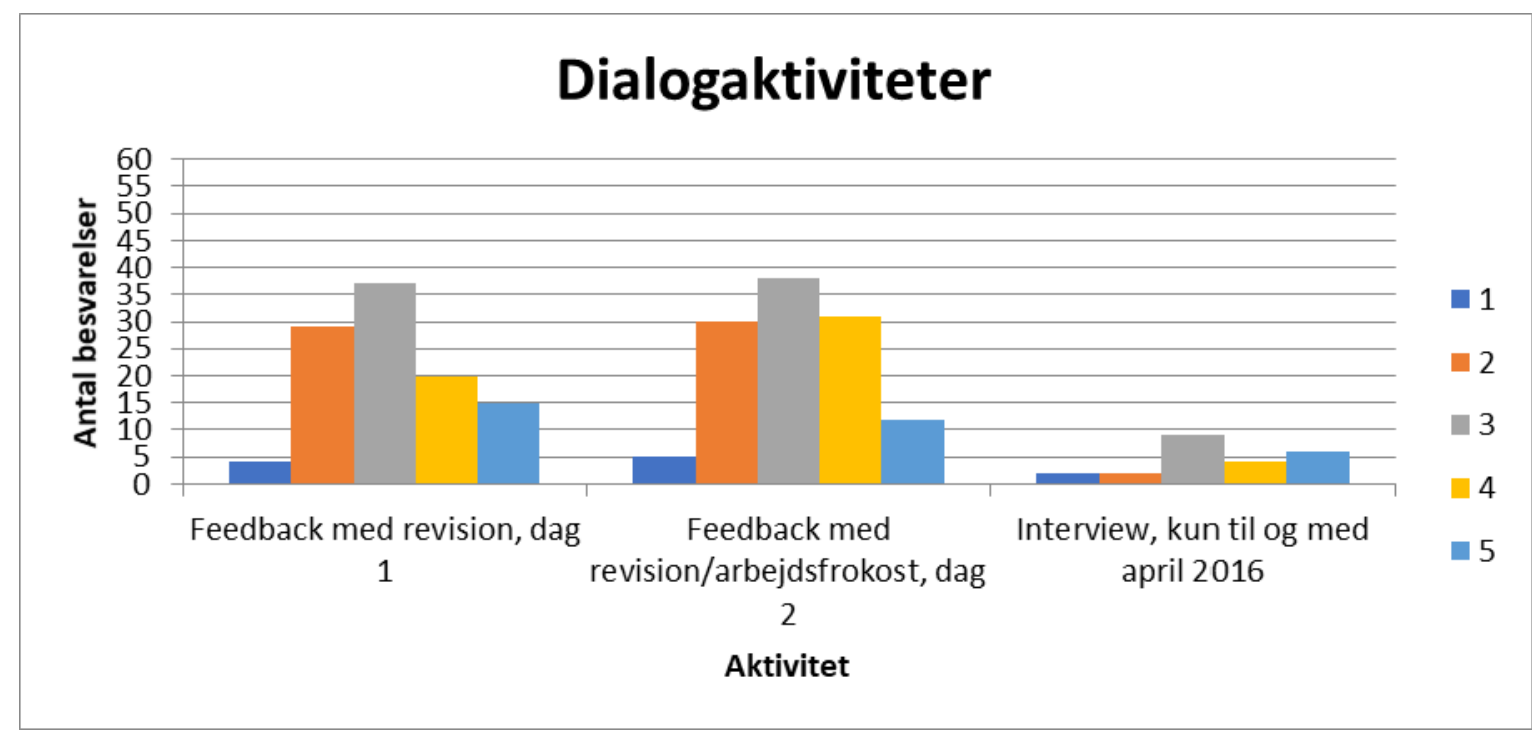

Figur 5. De studerendes udbytte af dialogaktiviteter (Score: 1 = intet udbytte, 5 = stort udbytte)

Efter de første tre skriveretreat stod det således klart, at der var behov for at justere programmet, så det bedre rammer de studerendes forståelseshorisont. Interviewelementet blev fjernet, og feedbackelementet på dag 1 blev forkortet. I foråret 2017 blev feedbackelementet på dag 2 ændret til arbejdsfrokost, hvor de studerende opfordres til at føre en uformel samtale om et emne af fælles interesse: Specialet. Dette gav plads til en halv times frokost, hvilket imødekom ændringsforslag om mere tid til frokost på dag 2. 
På trods af justeringerne er der samlet set over de fire år et blandet udbytte af dialogelementerne (se figur 5). Således har 70 ud af 105 studerende på dag 1 og 73 ud af 126 studerende på dag 2 haft intet eller et begrænset udbytte af feedback (score 1-3). Som skrivevejlederne Helle Hvass og Stine Heger skriver, skal peer feedback læres og rammesættes, før de studerende kan anvende det (Hvass \& Heger, 2018, s. 64). Hvass \& Heger skriver om peer feedback i studiegrupper, men også på et skriveretreat er der behov for en ramme at tale ud fra. Konkret opfordres de studerende til at lytte interesseret og stille kritiske spørgsmål, men det forventes ikke, at de kan kommentere på andre specialers faglige indhold.

På trods af kritikken handler flere kommentarer om, at det bedste ved at deltage i et skriveretreat er at være sammen med andre i samme situation, hvilket i sig selv har en positiv indflydelse på produktiviteten:

Sparing with other thesis students on what they were working on, the feeling of being forced to produce something that made me reach my goals (retreat april 2019),

og

sharing our (I am writing with a partner) thesis process with others and get feedback, finding some common ground and similarities between the challenges we face during the process of writing (retreat april 2019).

Dette aspekt genfindes hos Morss \& Murray, der viser, at den sociale kontakt og følelsen af 'at være i samme båd' er befordrende for skriveprocessen (Morss \& Murray, 2001, s. 44). Morss \& Murray (2001) evaluerede et styret skriveforløb, der varede seks måneder med jævnlige møder, men blot to dage kan være nok til at skabe bånd mellem deltagerne.

Ifølge Hvass \& Heger (2018) er feedback i forbindelse med opgaveskrivning "en vigtig forudsætning for, at studerende kan udvikle deres skriftlige akademiske færdigheder" (s. 59). På CBS' skriveretreat for specialestuderende er det dog også væsentligt, at de studerende selv opfatter indholdselementerne som meningsfulde og som havende en positiv effekt på produktiviteten, da de studerende i modsat fald vil fravælge at deltage.

Justeringerne i programmet har frigivet mere tid til skrivning, samtidig med at muligheden for at dele erfaringer med andre specialestuderende er bevaret. I foråret 2019 er der dog stadig ikke enighed om, at programmet indeholder den rette mængde dialog. Således skriver en studerende:

Personally I did not like to talk to other people about my thesis, because I have already explained it to myself on the computer (retreat april 2019),

mens andre studerende til spørgsmålet om ændringsforslag efterlyser mere peer feedback.

\section{Forsøg med endagsskriveretreat}

Især på skriveretreat, der udbydes på engelsk, er der en tendens til, at nogle studerende kun deltager den første dag uden at melde afbud til dag 2. I foråret 2019 blev det engelsksprogede skriveretreat derfor for første gang udbudt som et endagsarrangement. Dette retreat varede 5,5 timer og indeholdt to skriveheat på hver side af frokostpausen, målsætningmålopfyldelse, en non-stop skrivning og øvelsen pen på papir. Kommentarerne om det bedste ved at deltage i skriveretreatet handler primært om, at den strukturerende ramme uden forstyrrelser i et offline rum højner skriveproduktiviteten. Heri ligner de positive kommentarer således de positive kommentarer fra de undersøgte todagesskriveretreat. Ænndringsfor- 
slagene handler primært om, at fire skriveheat er for meget. Dette afspejles i den kvantitative del, hvor otte ud af 10 studerende havde et højt udbytte (score 4 og 5) af skriveheat 1 og 2, mens fem studerende havde et højt udbytte (score 4 og 5) af skriveheat 3 og 4 . Sammenholdt med at flere studerende foreslår længere pauser eller efterlyser mere dialog og/eller flere øvelser, indikerer det faldende udbytte, at det ikke er muligt at kompensere for den manglende dag ved at øge antallet af skriveheat og samtidig holde et højt skriveproduktivitetsniveau. Et udbytterigt endagsskriveretreat bør således formentlig indeholde mindre tid til skrivning og et større miks af indholdselementer, end der var i dette skriveretreats program. Davis et al. (2016) beskriver et endagsskriveretreat for ph.d.-studerende, hvor det på en enkelt dag lykkedes at skabe følelsen af at 'være i samme båd'. Forfatterne tilskriver den gode forplejning og de smukke omgivelser væk fra universitetet en del af æren for, at retreatet var udbytterigt for deltagerne (Davis et al., 2016, s. 64). Deres resultater kan derfor ikke umiddelbart sammenlignes med endagsretreatet på CBS, og da N=10 i nærværende undersøgelse, kan dette resultat kun opfattes som en indikation. Der er således behov for flere data for at kunne skabe den mest produktive sammensætning af et endagsretreat.

\section{Konklusion}

Murray \& Newton (2009)'s model for struktureret skriveretreat skaber øget produktivitet for specialestuderende, når modellen tilpasses lokale muligheder og behov, så der opstår holistisk indkapsling. Selvom CBS' skriveretreat for specialestuderende i modsætning til Murray \& Newtons struktureret skriveretreat foregår på universitetets grund, og dermed i vanlige rammer, er det muligt at skabe et fristed, hvor de studerende bare kan skrive uden distraktion. For specialestuderende er det en positiv forandring, at de bliver tvunget til at arbejde i et offlinemiljø. Fristedets befriende tvangselement fjerner risikoen for overspringshandlinger og bidrager dermed til emotionel indkapsling.

Den virksomme model for skriveretreat for specialestuderende består af en klar struktur og regler for adfærd, der skaber organisatorisk indkapsling. Det er centralt, at der er en facilitator, der udøver lederskab ved at sikre, at reglerne bliver fulgt af alle deltagere, at tidspunkterne i programmet bliver overholdt, og som leder de studerende igennem indholdselementerne, så de følger instruktionerne korrekt.

Programmet for skriveretreat for specialestuderende indeholder en vekslen mellem koncentreret skrivning, skriveteknikøvelser, dialog og pauser, og det indeholder dermed et større miks af indholdselementer, end der indgår i Murray \& Newtons model. Den ideelle længde på et skriveheat synes at være 75 minutter, og fem skriveheat fordelt på to dage synes at være maksimum, før produktiviteten begynder at falde. Omvendt må peer feedback, der også indgår i Murray \& Newtons model, og skriveteknikøvelser samlet set ikke optage for meget tid, da de studerende deltager, fordi de ønsker at skrive på deres speciale. Det er ikke påvist i analysen, at kun bestemte skriveteknikøvelser kan anvendes, men de studerende skal kunne arbejde med øvelserne på baggrund af en kort instruktion. Både peer feedback og skriveteknikøvelser bidrager til epistemologisk indkapsling, fordi de øger de studerendes forståelse af deres eget projekt og af skriveprocesser generelt.

Selvom epistemologisk indkapsling skabes delvist anderledes på CBS' skriveretreat for specialestuderende end på Murray \& Newtons struktureret skriveretreat, er alle tre indkapslinger tydeligt til stede, og der er derfor tale om holistisk indkapsling, hvilket forklarer, hvorfor specialestuderende har en øget produktivitet, når de er på skriveretreat, og dermed også 
hvorfor opfordringer til at holde flere skriveretreat er blandt de hyppigst forekommende ændringsforslag i data.

Andre ændringsforslag handler om at indføre en spørgetime med facilitator, da den øgede erkendelse, der opstår undervejs på skriveretreatet, genererer nye spørgsmål. Endvidere vil det ifølge de studerende give en mere kvalificeret peer feedback, hvis de studerende inddeles i grupper efter fælles faglighed. Endelig er der belæg for at eksperimentere med andre typer skriveøvelser. Disse ændringer må formodes at kunne bidrage yderligere til den epistemologiske indkapsling.

Ifølge Paltridge (2016, s. 208) har hans skriveretreatmodel en langtidsholdbar effekt hos deltagere, der efterfølgende danner skrivegrupper. Murray, Steckley \& MacLeod har derimod ikke fundet en langtidsholdbar effekt af struktureret skriveretreat på tidligere deltageres skrivevaner. For at opnå en sådan foreslår de blandt andet, at universiteterne indretter lokaler på universitetets grund, der kan tilbyde et arbejdsmiljø i stil med det, der skabes på CBS' skriveretreat for specialestuderende (Murray et al., 2012, s. 776). Specialestuderendes tidsperspektiv er knapt så langsigtet, da de typisk indleverer det færdige speciale få måneder efter skriveretreatet, men flere af deltagerne skriver i data, at de har en intention om at bruge elementer fra skriveretreatet på egen hånd. En fremtidig undersøgelse kunne således se på, om intentionen omsættes til praksis, og hvilken indflydelse det i givet fald har på specialeprocessen.

Skriveretreat for forskere er ikke for alle (Moore et al., 2010, s. 23), hvilket også gælder for skriveretreat for specialestuderende. Analysen bygger på data fra studerende, der har deltaget i et skriveretreat. Der er ingen data fra de studerende, der valgte at springe fra, ej heller fra studerende, der kender til denne specialeressources eksistens, men vælger ikke at melde sig til. Det er således ikke muligt at konkludere noget om disse grupper af studerende. Murray har sammen med Larissa Kempenaar undersøgt en særlig version af det struktureret skriveretreat for forskere, der var udvalgt til at deltage på grund af manglende publiceringsaktivitet (Kempenaar \& Murray, 2018). Heri konkluderer de, at deltagerne fik mere viden om både skriveprocesser og skriveteknikker af at være på skriveretreat, også selvom der ikke indgik øvelser i skriveteknikker på dette skriveretreat. Det indikerer, at struktureret skriveretreat kan forbedre skriveprocesser, også hos deltagere med særligt behov for skrivehjælp. Der kan derfor være belæg for at undersøge ikke-deltagende studerendes skrivevaner, samt hvilke potentialer der måtte være for at hjælpe disse studerende til en (endnu) bedre specialeproces.

\section{Referencer}

Anchorage Education (2019): Rowena Murray Writing Retreats in Scotland, http://www.anchorage-education.co.uk/, sidst fundet 9. juli 2019

Ankersborg, V. \& Pogner, K.-H. (2016): (Almost) becoming an academic. Master's thesis students' approaches to writing at Copenhagen Business School, conference paper, LUNAS

Dickson-Swift, V., James, E. L., Kippen, S., Talbot, L., Verrinder, G. \& Ward, B. (2009): A nonresidential alternative to off campus writers' retreats for academics. Journal of Further and Higher Education, 33:3, s. 229-239 
Davis, G., Wright, H. \& Holley, D. (2016): Write away from it all! The value of running a writing retreat for doctoral students. Practitioner research in Higher Education, 10:2, s. 54-66

Girardeau, L., Rud, A. \& Trevisan, M. (2014): Jumpstarting junior faculty motivation and performance with focused writing retreats. The Journal of Faculty Development, 28:1, s. 3344

Hvass, H. \& Heger, S. (2018): Brugbar peer feedback: Instruktion og træning, før de studerende selv skal give og modtage. Dansk Universitetspaedagogisk Tidsskrift, 13:25, s. 59-70

Keiding, Tina B. (2012): Del af eller uden for fællesskabet? - Rummet som medskaber af uformelle læreprocesser. Dansk Universitetspœedagogisk Tidsskrift, 7:13, s. 41-53

Kempenaar, L. \& Murray, R. (2018): Widening access to writing support: Beliefs about the writing process are key. Journal of Further and Higher Education, s. 1-11, DOI: 10.1080/0309877X.2018.1450964

Kornhaber, R., Cross, M., Betihavas, V. \& Bridgman, H. (2016): The benefits and challenges of academic writing retreats: An integrative review. Higher Education Research \& Development, 35:6, s.1210-1227

Moore, Sarah (2003): Writer's retreats for academics: Exploring and increasing the motivation to write. Journal of Further and Higher Education, 27:3, s. 333-342

Moore, S., Murphy, M. \& Murray, R. (2010): Increasing Academic Output and Supporting Equality of Career Opportunity in Universities: Can Writers' Retreats Play a Role? The Journal of Faculty Development, 24:3, s. 21-30

Morss, K. \& Murray, R. (2001): Researching Academic Writing within a Structured Programme: Insights and outcomes. Studies in Higher Education, 26:1, s. 35-52

Mueller, P.A. \& Oppenheimer, D.M. (2014, rev. udg. 2018): The pen is mightier than the keyboard: Advantages of longhand over laptop note taking. Psychological Science, 25, s. 1159-1168

Murray, R. \& Newton, M. (2009): Writing retreat as structured intervention: Margin or mainstream? Higher Education Research \& Development, 28:5, s. 541-553

Murray, R., Steckley, L. \& MacLeod, I. (2012): Research leadership in writing for publication: A theoretical framework. British Educational Research Journal, 38:5, s. 765-781

Papen, U. \& Thériault, V. (2018): Writing retreats as a milestone in the development of PhD students' sense of self as academic writers. Studies in Continuing Education, 40:2, s. 166-180

Paltridge, B. (2016): Writing retreats as writing pedagogy. Writing \& Pedagogy, 8:1, s. 199-213

Rienecker, Lotte (1996): Tekster til tiden, Dansk Psykologisk Forlag

Rienecker, L., Stray Jørgensen P. \& Gandil, M. (2. udg. 2016): Skriv artikler, Forlaget Samfundslitteratur

Swaggerty, E., Atkinson, T., Faulconer, J. \& Griffith, R. (2011): Academic writing retreat: A time for rejuvenated and focused writing. The Journal of Faculty Development, 25:1, s. 5-11 